\title{
Impact of Industrial Symbiosis on Sustainability
}

\author{
Ashok Kumar Pandey*, Ravi Prakash \\ Department of Mechanical Engineering, Motilal Nehru National Institute of Technology, Allahabad, India \\ Email: *akpandeygp@gmail.com, rprakash234@gmail.com
}

How to cite this paper: Pandey, A.K. and Prakash, R. (2019) Impact of Industrial Symbiosis on Sustainability. Open Journal of Energy Efficiency, 8, 81-93. https://doi.org/10.4236/ojee.2019.82006

Received: April 9, 2019

Accepted: June 25, 2019

Published: June 28, 2019

Copyright $\odot 2019$ by author(s) and Scientific Research Publishing Inc. This work is licensed under the Creative Commons Attribution International License (CC BY 4.0).

http://creativecommons.org/licenses/by/4.0/

\section{c) (i) Open Access}

\begin{abstract}
This paper quantitatively examines the impact of industrial symbiosis on sustainability. The quantitative approach, as developed by the authors, is based on the concept of Industrial Sustainability Index (ISI), which represents the socio-economic benefit of an industry per unit of its carbon emissions. The ISI was evaluated for a chemical production plant both in independent and symbiotic modes with different energy technologies. The ISI value for the chemical production plant in independent mode was found to be 6 units. This was three times more than in the case of the existing symbiotic mode with an adjacent pulp \& paper industry having coal fired CHP plant. With the adoption of more energy efficient technologies e.g. natural gas based combined cycle power plant and solar PV electricity generation; the ISI in the modified symbiotic mode can be increased to 18 units. The results indicate that industrial symbiosis can help in sustainability improvement when the technologies used by the industries are energy efficient.
\end{abstract}

\section{Keywords}

Industrial Symbiosis, $\mathrm{CO}_{2}$ Emissions, Industrial Sustainability Index, Socio-Economic Benefit

\section{Introduction}

The Industrial sector involves various types of resource consumption e.g. materials, energy and manpower with associated emissions and wastes. Industrial sector consumed $175.82 \mathrm{EJ}$ of primary energy and contributed nearly $21 \%$ (i.e. $15.44 \mathrm{GtCO}_{2}$ ) of the total global emissions in 2010 [1]. Indian industrial sector approximately used $57.71 \%$ of the total national energy consumption for the year of 2017 [2]. Due to huge resource consumption and carbon emissions, the industrial sector needs to be examined for its sustainability in order to provide 
an assessment of the long-term benefit of this sector to society. Such sustainability assessments fall in the domain of industrial ecology (IE), which defines the industry as an artificial ecosystem that operates as a natural ecosystem with the interdependence of its various components [3] [4].

Industrial sustainability is an important factor for socio-economic development and environmental protection across the world [5] [6] [7] [8]. As per Sustainable Development Goal (SDG 09), industrial sustainability has to address all the three aspects i.e. social, economic, and environmental [9]. Out of three aspects, industrialization is closely related to economic growth, job creation, resources consumption as well as environment pollution [10] [11] [12] [13]. Therefore, sustainable development in the industrial sector must be adopted to achieve the goal of sustainability.

The commonly used metric for assessing energy performance in the industrial sector has been the Specific Energy Consumption (SEC). However, the SEC is variable depending upon the type of industrial product as well as the scale of industrial production [14]. Another parameter developed for industrial sustainability is called Eco-efficiency [15]. It considers only economic output and carbon emissions to estimate the product's impact. It is a ratio of the value of a product to the environmental impact of the product. It suffers from two drawbacks: 1) physical resource inputs are not considered; 2) social sustainability is not addressed [16].

In order to overcome the above-mentioned deficiencies of SEC and eco-efficiency, a new Industrial Sustainability Index (ISI) was proposed by Pandey and Prakash, 2018 [17]. It was meant to address all the three sustainability goals (social, economic and environmental) and it can also compare different types of industries such as small, medium or large scale as well as for any type of product.

The Industrial symbiosis approach is one of the sustainable options that may reduce the overall impact of inter-connected industries. Such an interconnection engages separate industries in a collective approach to provide a competitive advantage by involving physical exchange of materials, energy, water, and/or byproducts. Taddeo et al., 2012 [18] reported workers employment data for an Italian industrial site operated with the concept of industrial symbiosis and they found the increase in employment by 174\% during the period 2007 to 2008 . Zhang et al. [19] analyzed the impact of industrial symbiosis in the iron and steel industry in China. They observed a reduction in net carbon emissions per ton of steel with some energy efficient technologies e.g. through Combined Cycle Power Plant. Notarnicola et al., 2016 [20] identified the industrial sectors and firms of the Taranto industrial district that could be involved in symbiotic activities and it may help to assimilate complete waste of $2.8 \mathrm{Mt}$ which may avoid over 130 $\mathrm{M} € /$ year of disposal costs and its environmental impacts deriving from 17 toe/year of energy use and 37,814 $\mathrm{tCO}_{2 \mathrm{eq}}$ /year of GHG emissions.

Berkel et al., 2009 [21] presented a quantitative assessment of urban and in- 
dustrial symbiosis in Japan and documented benefits of such a symbiosis in steel, cement, chemical, and paper firms along with their spin-off recycling businesses; and reported that material exchanges divert annually at least 565,000 tons of waste from incineration or landfill. Ohnishi et al., 2017 [22] examined the Carbon Footprint of the industrial area in Kawasaki Eco-town (a coastal industrial area of Kawasaki City), which indicated that reduction of waste and by-products through industrial symbiosis decreased $13.8 \%$ of $\mathrm{CO}_{2 \mathrm{e}}$ emissions. The LCA analysis was used with industrial symbiosis concept on the synthetic gas industry chain of Songmudao chemical industrial park in Dalian, China, which demonstrated life cycle environmental benefits through sharing of by-product resources by as much as 13.63 thousand TJ of primary energy and 1218 thousand $\mathrm{tCO}_{2 \mathrm{e}}$ of GHG emission [23].

The chemical sector is one of the most energy and resource consuming in India [24], and therefore any environmental impact reduction will be highly significant for improving industrial sustainability. In the Indian context, energy conservation studies in dairy [25] and pulp \& paper industries [26] show significant energy and carbon saving potential through process improvement and co-generation technologies.

This study aims to examine the possible improvement of industrial sustainability through the industrial symbiosis of two existing chemical sector industries (i.e. Orient Papers Mills \& Hukum Chand Jute Industry) located at Amlai (Madhya Pradesh), India. Generally, it is assumed that the sustainability of the industrial sector would improve with symbiosis. However, it may not be true in all cases, as the impact of symbiosis on sustainability may depend upon the efficiency of various technologies used in energy and material exchange as examined through this study.

\section{Methodology}

For quantitative assessment of industrial sustainability, a new Industrial Sustainability Index (ISI) was proposed by Pandey and Prakash, 2018 [17]. The Industrial Sustainability Index (ISI) is a simplified tool, which represents the socio-economic benefit of any type of industry per unit of its carbon emissions. Hence, the ISI as proposed assesses social, economic and environmental goals of any type or types of industries (i.e. small, medium or large scale). It represents the socio-economic-environmental benefit from industry in terms of "Million Rs. Persons per ton of $\mathrm{CO}_{2}$ emission", which would be referred to as "units" of ISI. The concept of ISI is illustrated through Figure 1. The expression of the ISI is as follows:

$$
\mathrm{ISI}=\frac{(\mathrm{RVA}) \times(\mathrm{EMP})}{\mathrm{CO}_{2} \text { emissions }}
$$

where,

The term "RVA" represents the resource value addition (i.e. the difference of the total annual economic values of material \& energy outputs (products) and 




Figure 1. Sustainability analysis for an industrial system.

that of inputs); it's represented here as million Rs. per year. The limitation of RVA using Indian currency (Rs.) can be overcome if the RVA is represented in US Dollars with purchasing power parity (i.e. PPP \$). The use of purchasing power parity can make the RVA units universal in nature rather than being country specific.

The term "EMP" represents the total number of persons employed by the industry in a year; and " $\mathrm{CO}_{2}$ emissions" represent the total annual carbon dioxide emissions by the industry during production (in $\mathrm{tCO}_{2}$ /year).

The above-mentioned concept of ISI was applied to a pulp \& paper industry [17], and its improvement potential was examined by fuel substitution and combined cycle power generation. This study extends this work by examining the impact of industrial symbiosis on sustainability improvement. There are many situations where the exchange of materials and energy may take place between two or more industries in order to provide mutual benefit. Such a symbiosis may lead to reduced transportation costs of materials and goods as well as that of energy supply in various forms such as fuels, steam or electricity. This would also have a concomitant effect of reduced carbon emissions. In case waste byproduct of an industry is utilized as raw-material input for another industry, then the waste treatment costs are also avoided thus providing additional benefits.

In order to quantitatively assess the overall sustainability impact of symbiosis, the values of ISI need to be computed for a particular industry, both in the independent mode as well as in the symbiotic mode. If an improvement in ISI value is observed with symbiosis, then only the industry should adopt such a mode.

The above methodology has been applied for the case study examined in this work.

\section{Survey and Data Collection for the Case Study}

The case study selected for this work is a soda ash chemical industry (Hukum Chand Jute Industry (HJI) located at Amlai (M.P), India), which works in a symbiotic mode with an adjacent pulp \& paper industry (Orient Paper Mills (OPM) located at Amlai (M.P), India). The electricity and steam produced by 
the paper industry supply all the energy needs of the soda ash chemical industry. Further, the chemical industry provides all the chemical feedstocks (i.e. Caustic soda, Liquid Chlorine, and Sodium Hypo Chlorite) required for the pulp \& paper industry. Thus both industries get benefited by reduced costs of energy and raw materials. Such symbiosis is depicted in Figure 2.

The chemical production plant of HJI has four major outputs: Caustic Soda Lie, $\mathrm{Cl}_{2}$ gas, Liquid $\mathrm{HCl}$, Sodium Hypo-Chlorite. The raw-material input to the plant is salt, soda ash, and barium chloride. The electrical and thermal energy demands of the industry are met through OPM. The annual electricity generated by the OPM was about $158.4 \mathrm{GWh}$ in the year of 2017. Out of this $71.3 \mathrm{GWh}$, electricity per year (i.e. $45 \%$ of the total electricity generation at OPM) was supplied to the HJI. Only $38 \mathrm{MWh}$ per year of electricity is imported from the grid as an emergency back-up. Saturated steam (bled from the main steam header of the OPM boiler) is supplied to the HJI at $10-12$ bar and $180^{\circ} \mathrm{C}-190^{\circ} \mathrm{C}$ for meeting its process needs.

Data regarding the detailed input resource consumption and product outputs of the HJI were collected from the Data and Record Center Office of the HJI industry. This data has been used in the computation of RVA, $\mathrm{CO}_{2}$ emissions, and the ISI as presented in the results.

Prior to 2012, the HJI unit was working in an independent mode in terms of the energy supply. The power needs of the unit were being met through Madhya Pradesh Electricity Board (a state-run utility company), and process steam was generated through a coal-fired boiler. As per the information provided by the HJI, the company's turnover and employment have been practically the same. Such an independent mode of the unit is depicted in Figure 3.

Figure 4 provides the process flow diagram of the chemical production plant at HJI. Figure 5 \& Figure 6 provide the electricity flow diagram and steam flow diagram of the HJI plant respectively.

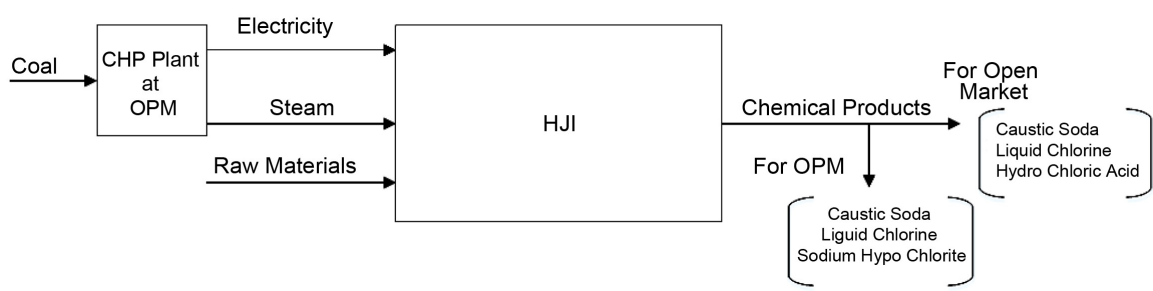

Figure 2. Existing symbiotic mode of OPM and HJI industries.

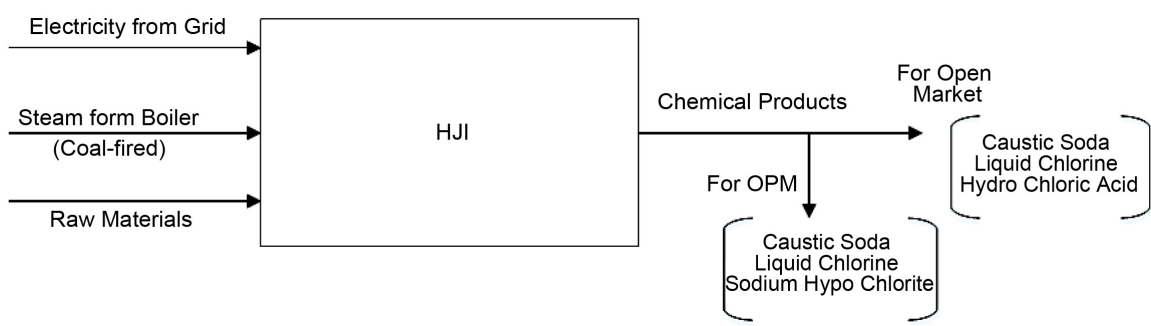

Figure 3. Independent mode of HJI industry. 


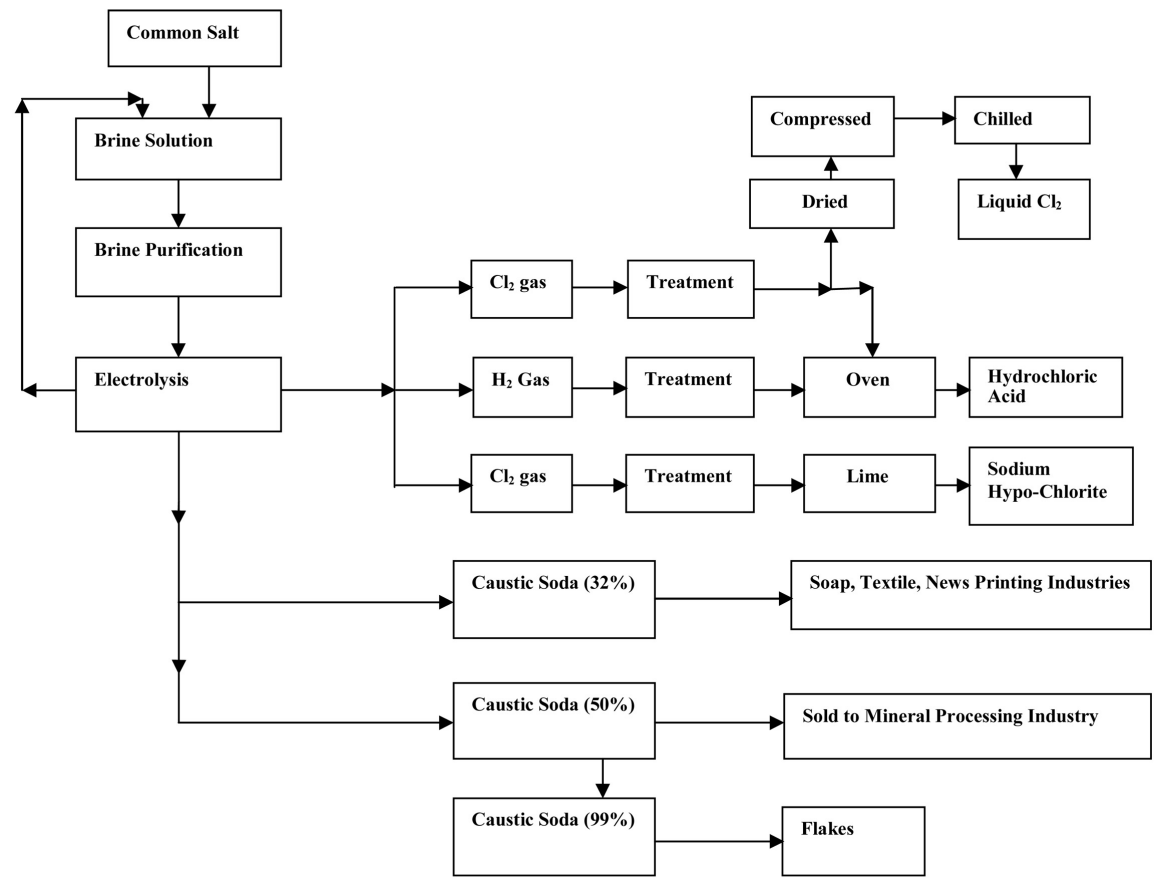

Figure 4. Process flow diagram for the HJI production plant.

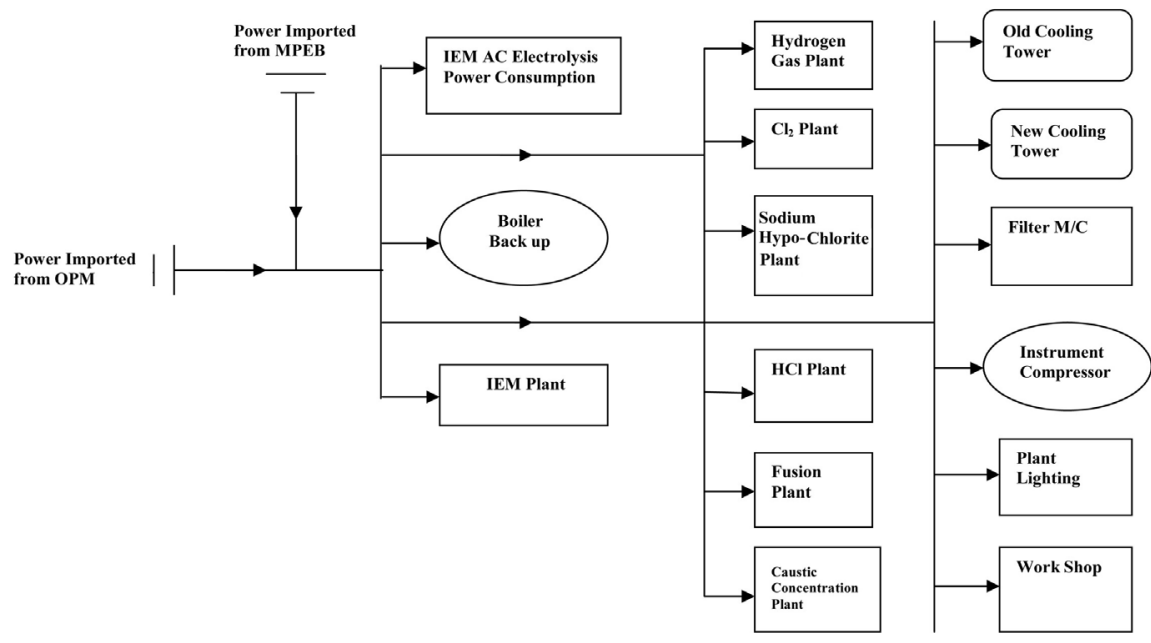

Figure 5. Electricity flow diagram of the HJI production plant.

\section{Results and Discussion}

\subsection{ISI Evaluation for Independent Mode}

The detailed input resource consumption and product outputs of the HJI in independent mode are provided in Table 1 and illustrated through Figure 3. The corresponding $\mathrm{CO}_{2}$ emissions are shown in Table 2.

\subsection{ISI Evaluation for Existing Symbiotic Mode}

In the existing symbiotic mode, all the energy (electricity and steam) requirements of HJI are being met through the coal-fired CHP plant of OPM. The material exchange has remained constant between the two units. For this mode, the 


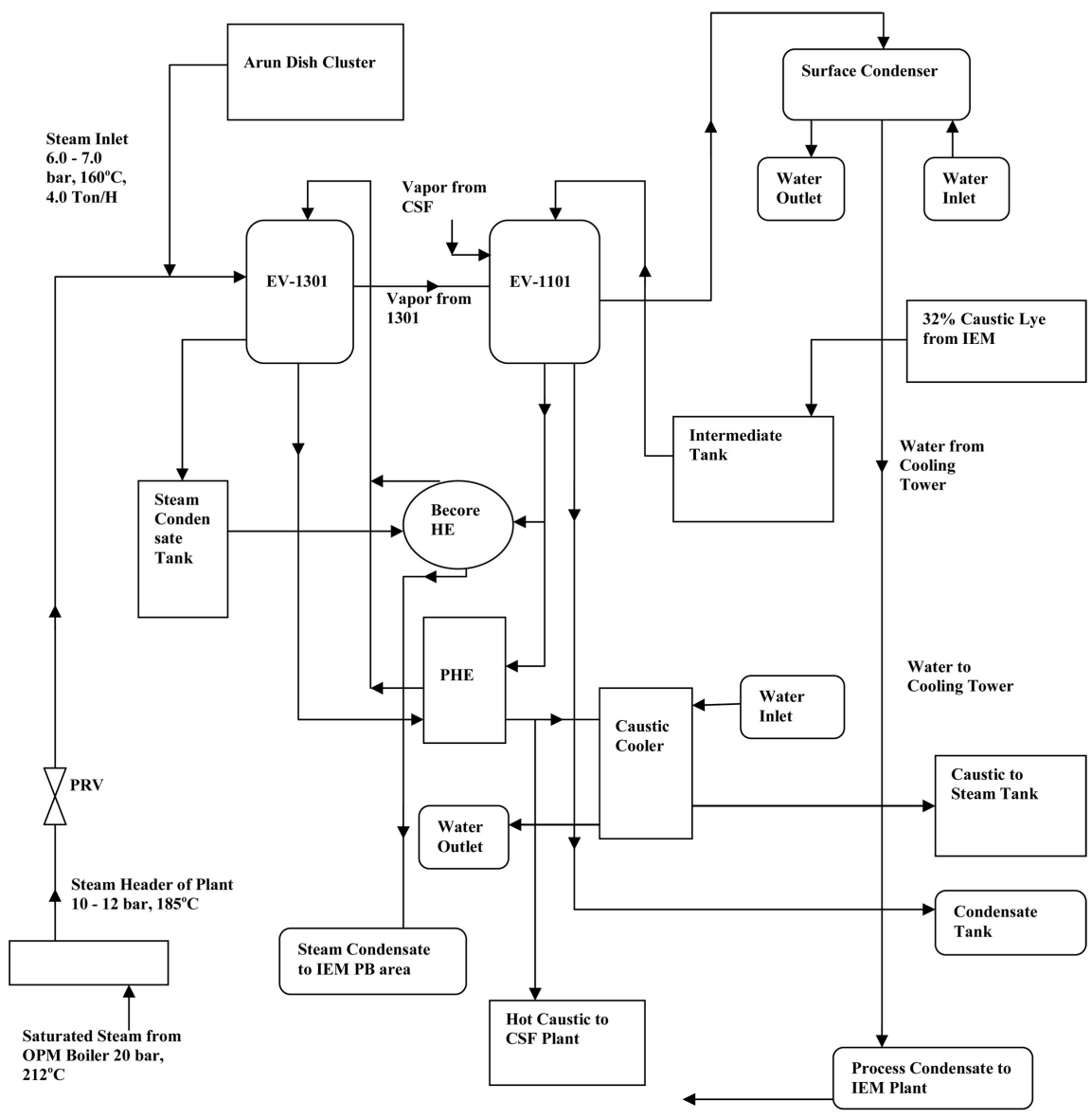

Figure 6. Steam flow diagram of the HJI production plant.

annual material and energy consumption data is given in Table 3 and illustrated in Figure 2. The corresponding carbon emissions are shown in Table 4.

Thus, the ISI for existing symbiotic mode is less than that in the independent mode. This is due to the inefficient power generation from the coal-fired CHP plant at OPM. The boiler pressure used in the CHP plant is only 65 bar, while power available from the grid is generated with steam from high pressure $(\sim 200$ bar) boilers. Therefore coal consumption and $\mathrm{CO}_{2}$ emissions per unit of electricity generation from the grid are less than that in the CHP plant.

\subsection{ISI Evaluation for the Modified Symbiotic Mode of OPM (with NGCC) and HJI (with SPV)}

In order to improve the ISI of HJI in symbiotic mode, the following modifications have been proposed. The electricity generation at the OPM can be made much more efficient by employing a natural gas based combined cycle (NGCC) plant. This can be economically realized through re-powering of the existing coal-based CHP plant. The NGCC plant will have a natural gas fuelled gas turbine plant as a topping cycle and steam generated through a heat recovery steam generator (HRSG) will be used for the steam turbine bottoming plant. Such an arrangement was analysed by Pandey and Prakash, 2018 [17] showing significant 
Table 1. Annual material and energy consumption for HJI in independent mode.

\begin{tabular}{|c|c|c|c|c|}
\hline $\begin{array}{l}\text { Sl. } \\
\text { No. }\end{array}$ & $\begin{array}{c}\text { Item } \\
\text { (Input/Output) }\end{array}$ & Quantity & $\begin{array}{c}\text { Price/Cost rate } \\
\text { (Rs) }\end{array}$ & $\begin{array}{l}\text { Total Price/Cost } \\
\text { (million Rs) }\end{array}$ \\
\hline 01 & $\begin{array}{l}\text { Electricity Import from } \\
\text { MPEB Grid (Input) }\end{array}$ & $71,318,000 \mathrm{kWh}$ & $6.00 / \mathrm{kWh}$ & 428 \\
\hline 02 & $\begin{array}{l}\text { Steam consumption } \\
\text { (coal based) } \\
\text { (Input) }\end{array}$ & $3932 \mathrm{MT}$ & $3000 / \mathrm{MT}$ & 12 \\
\hline 03 & $\begin{array}{l}\text { High-speed diesel } \\
\text { (Input) }\end{array}$ & $10 \mathrm{MT}$ & $52,000 / \mathrm{MT}$ & 0.52 \\
\hline 04 & Salt (Input) & $54,509 \mathrm{MT}$ & $3000 / \mathrm{MT}$ & 164 \\
\hline 05 & Soda Ash (Input) & $70 \mathrm{MT}$ & $20,000 / \mathrm{MT}$ & 1.4 \\
\hline 06 & $\begin{array}{l}\text { Barium Chloride } \\
\text { (Input) }\end{array}$ & $216 \mathrm{MT}$ & $100,000 / \mathrm{MT}$ & 21.6 \\
\hline 07 & $\begin{array}{l}\text { Caustic Soda Lie } \\
\text { (Output) }\end{array}$ & $34,942 \mathrm{MT}$ & $40,000 / \mathrm{MT}$ & 1398 \\
\hline 08 & $\mathrm{Cl}_{2}$ gas (Output) & $19,037 \mathrm{MT}$ & $15,000 / \mathrm{MT}$ & 286 \\
\hline 09 & Liquid $\mathrm{HCl}$ (Output) & $33,396 \mathrm{MT}$ & $10,000 / \mathrm{MT}$ & 334 \\
\hline 10 & $\begin{array}{c}\text { Sodium Hypo-Chlorite } \\
\text { (Output) }\end{array}$ & $2081 \mathrm{MT}$ & $5000 / \mathrm{MT}$ & 10.4 \\
\hline
\end{tabular}

Table 2. Annual $\mathrm{CO}_{2}$ emissions from energy inputs for $\mathrm{HJI}$ in independent mode.

\begin{tabular}{|c|c|c|c|c|c|}
\hline $\begin{array}{l}\text { SL. } \\
\text { NO. }\end{array}$ & Item & Quantity & $\begin{array}{c}\text { Average } \\
\text { Calorific } \\
\text { Value } \\
(\mathrm{CV}) \\
(\mathrm{MJ} / \mathrm{kg})\end{array}$ & $\begin{array}{c}\text { Specific } \\
\text { emission } \\
\text { factor } \\
\left(\mathrm{kgCO}_{2} / \mathrm{kg}\right. \\
\text { fuel })[27] .\end{array}$ & $\begin{array}{c}\text { Annual } \mathrm{CO}_{2} \\
\text { Emissions } \\
\left(\mathrm{tCO}_{2}\right)\end{array}$ \\
\hline 01 & Coal & $3932 \mathrm{MT}$ & 17.6 & 1.66 & 6527 \\
\hline 02 & $\begin{array}{l}\text { High-Speed } \\
\text { Diesel }\end{array}$ & $10 \mathrm{MT}$ & 35.0 & 2.76 & 27.6 \\
\hline 03 & $\begin{array}{c}\text { Electricity from } \\
\text { MPEB Grid }\end{array}$ & $71,318,000 \mathrm{kWh}$ & - & $\begin{array}{c}0.88 \mathrm{~kg} \mathrm{CO}_{2} \\
\text { per kWh }\end{array}$ & 62,760 \\
\hline \multicolumn{6}{|c|}{ Total Annual $\mathrm{CO}_{2}$ Emissions $=69,314.6 \mathrm{tCO}_{2}$} \\
\hline
\end{tabular}

For this production mode of HJI, the following results were obtained: RVA $=1401$ million Rs, Emp $=300$ persons, $\mathrm{CO}_{2}$ Emissions $=69,314.6 \mathrm{tCO}_{2}$, Hence, $\mathrm{ISI}=6.0$ units.

improvement in ISI for the OPM plant. Such an efficiency improvement will also help in ISI improvement of HJI in symbiotic mode.

Additional improvements and partial fulfillment of electrical demand of HJI plant with solar PV-rooftop system $\left(2 \mathrm{MW}_{\mathrm{p}}\right)$ have also been proposed for further reducing the carbon emissions from HJI plant. The simulation of the solar PV system has been done by the RET screen software. For use of solar PVrooftop system $\left(2 \mathrm{MW}_{\mathrm{p}}\right)$, the roof area required for the solar collector is 14,545 $\mathrm{m}^{2}$. The electrical energy generated by solar PV-rooftop system in a year is 3062 $\mathrm{MWh}_{\mathrm{e}}$. 
Table 3. Annual material and energy consumption for HJI in the existing symbiotic mode.

\begin{tabular}{|c|c|c|c|c|}
\hline $\begin{array}{l}\text { Sl. } \\
\text { No. }\end{array}$ & $\begin{array}{c}\text { Item } \\
\text { (Input/Output) }\end{array}$ & Quantity & $\begin{array}{c}\text { Price/Cost rate } \\
\text { (Rs) }\end{array}$ & $\begin{array}{l}\text { Total Price/Cost } \\
\text { (million Rs) }\end{array}$ \\
\hline 01 & $\begin{array}{l}\text { Electricity Import } \\
\text { from MPEB Grid } \\
\text { (Input) }\end{array}$ & $38,000 \mathrm{kWh}$ & $6.00 / \mathrm{kWh}$ & 0.23 \\
\hline 02 & $\begin{array}{c}\text { Electricity Import } \\
\text { from OPM (coal } \\
\text { based) } \\
\text { (Input) }\end{array}$ & $71,280,000 \mathrm{kWh}$ & $6.00 / \mathrm{kWh}$ & 428 \\
\hline 03 & $\begin{array}{c}\text { Steam consumption } \\
\text { from OPM } \\
\text { (coal-based) } \\
\text { (Input) }\end{array}$ & $3386 \mathrm{MT}$ & $3000 / \mathrm{MT}$ & 10.15 \\
\hline 04 & Salt (Input) & $54,509 \mathrm{MT}$ & $3000 / \mathrm{MT}$ & 164 \\
\hline 05 & $\begin{array}{l}\text { Soda Ash } \\
\text { (Input) }\end{array}$ & $70 \mathrm{MT}$ & $20,000 / \mathrm{MT}$ & 1.4 \\
\hline 06 & $\begin{array}{l}\text { Barium Chloride } \\
\text { (Input) }\end{array}$ & $216 \mathrm{MT}$ & $100,000 / \mathrm{MT}$ & 21.6 \\
\hline 07 & $\begin{array}{l}\text { Caustic Soda Lie } \\
\text { (Output) }\end{array}$ & $34,942 \mathrm{MT}$ & $40,000 / \mathrm{MT}$ & 1398 \\
\hline 08 & $\begin{array}{l}\mathrm{Cl}_{2} \text { gas } \\
\text { (Output) }\end{array}$ & $19,037 \mathrm{MT}$ & $15,000 / \mathrm{MT}$ & 286 \\
\hline 09 & $\begin{array}{l}\text { Liquid HCl } \\
\text { (Output) }\end{array}$ & $33,396 \mathrm{MT}$ & $10,000 / \mathrm{MT}$ & 334 \\
\hline 10 & $\begin{array}{l}\text { Sodium } \\
\text { Hypo-Chlorite } \\
\text { (Output) }\end{array}$ & $2081 \mathrm{MT}$ & $5000 / \mathrm{MT}$ & 10.4 \\
\hline
\end{tabular}

Table 4. Annual $\mathrm{CO}_{2}$ emissions from energy inputs for $\mathrm{HJI}$ in the existing symbiotic mode.

\begin{tabular}{|c|c|c|c|c|c|}
\hline $\begin{array}{l}\text { SL. } \\
\text { No. }\end{array}$ & Item & Quantity & $\begin{array}{c}\text { Average } \\
\text { Calorific } \\
\text { Value }(\mathrm{CV}) \\
(\mathrm{MJ} / \mathrm{kg})\end{array}$ & $\begin{array}{c}\text { Specific } \\
\text { emission } \\
\text { factor } \\
\left(\mathrm{kgCO}_{2} / \mathrm{kg}\right. \\
\text { fuel) }[27] \text {. }\end{array}$ & $\begin{array}{c}\text { Annual } \mathrm{CO}_{2} \\
\text { Emissions } \\
\quad\left(\mathrm{tCO}_{2}\right)\end{array}$ \\
\hline 01 & Coal & $127,252 \mathrm{MT}$ & 17.6 & 1.66 & 211,238 \\
\hline 02 & Furnace Oil & $589 \mathrm{MT}$ & 42.0 & 3.31 & 1950 \\
\hline 03 & $\begin{array}{l}\text { High-Speed } \\
\text { Diesel }\end{array}$ & $6.9 \mathrm{MT}$ & 35.0 & 2.76 & 19 \\
\hline 04 & Charcoal & $0.43 \mathrm{MT}$ & 29.0 & 2.30 & 0.98 \\
\hline 05 & $\begin{array}{l}\text { Electricity from } \\
\text { MPEB Grid }\end{array}$ & $38,000 \mathrm{kWh}$ & - & $\begin{array}{c}0.88 \mathrm{~kg} \mathrm{CO}_{2} \\
\text { per } \mathrm{kWh}\end{array}$ & 33.44 \\
\hline \multicolumn{6}{|c|}{ Total Annual $\mathrm{CO}_{2}$ Emissions $=213,241.4 \mathrm{tCO}_{2}$} \\
\hline
\end{tabular}

For this production mode of HJI, the following results were obtained: RVA $=1403$ million Rs, EMP $=300$ persons, total annual $\mathrm{CO}_{2}$ emissions $=213,241 \mathrm{tCO}_{2}$. Hence, ISI for the existing system is evaluated as 2.0 units. 
The above two modifications in symbiotic mode are depicted through Figure 7. The annual material and energy inputs and outputs are shown in Table 5 and corresponding carbon emissions are shown in Table 6.



Figure 7. Modified symbiotic mode of OPM (with NGCC) and HJI (with SPV).

Table 5. Annual material and energy consumption for HJI in the modified symbiotic mode.

\begin{tabular}{|c|c|c|c|c|}
\hline $\begin{array}{l}\text { Sl. } \\
\text { No. }\end{array}$ & $\begin{array}{c}\text { Item } \\
\text { (Input/Output) }\end{array}$ & Quantity & $\begin{array}{c}\text { Price/Cost rate } \\
\text { (Rs) }\end{array}$ & $\begin{array}{l}\text { Total Price/Cost } \\
\text { (million Rs) }\end{array}$ \\
\hline 01 & $\begin{array}{l}\text { Electricity Import from } \\
\text { MPEB Grid (Input) }\end{array}$ & $38,000 \mathrm{~kW}$ & $6.00 / \mathrm{kW}$ & 0.23 \\
\hline 02 & $\begin{array}{l}\text { Electricity Import from } \\
\text { OPM (Input) }\end{array}$ & $68,218,000 \mathrm{~kW}$ & $6.00 / \mathrm{kW}$ & 313.7 \\
\hline 03 & $\begin{array}{l}\text { Steam consumption from } \\
\text { OPM (Natural gas } \\
\text { consumed) (Input) }\end{array}$ & $1176 \mathrm{MT}$ & $10,000 / \mathrm{MT}[28]$ & 12 \\
\hline 04 & Salt (Input) & $54,509 \mathrm{MT}$ & $3000 / \mathrm{MT}$ & 164 \\
\hline 05 & Soda Ash (Input) & $70 \mathrm{MT}$ & $20,000 / \mathrm{MT}$ & 1.4 \\
\hline 06 & Barium Chloride (Input) & $216 \mathrm{MT}$ & $100,000 / \mathrm{MT}$ & 21.6 \\
\hline 07 & $\begin{array}{l}\text { Electricity Produced from } \\
\text { SPV (Output) }\end{array}$ & $3,062,000 \mathrm{~kW}$ & $6.00 / \mathrm{kW}$ & 18.3 \\
\hline 08 & Caustic Soda Lie (Output) & $34,942 \mathrm{MT}$ & $40,000 / \mathrm{MT}$ & 1398 \\
\hline 09 & $\mathrm{Cl}_{2}$ gas (Output) & $19,037 \mathrm{MT}$ & $15,000 / \mathrm{MT}$ & 286 \\
\hline 10 & Liquid $\mathrm{HCl}$ (Output) & 33,396 MT & $10,000 / \mathrm{MT}$ & 334 \\
\hline 11 & $\begin{array}{c}\text { Sodium } \\
\text { Hypo-Chlorite (Output) }\end{array}$ & $2081 \mathrm{MT}$ & $5000 / \mathrm{MT}$ & 10.4 \\
\hline
\end{tabular}

Table 6. $\mathrm{CO}_{2}$ emissions for $\mathrm{HJI}$ in the modified symbiotic mode.

\begin{tabular}{|c|c|c|c|c|c|}
\hline Sl. No. & Item & Quantity & $\begin{array}{c}\text { Average } \\
\text { Calorific } \\
\text { Value }(\mathrm{CV}) \\
(\mathrm{MJ} / \mathrm{kg})\end{array}$ & $\begin{array}{c}\text { Specific } \\
\text { emission } \\
\text { factor } \\
\left(\mathrm{kgCO}_{2} / \mathrm{kg}\right. \\
\text { fuel) }[27] \text {. }\end{array}$ & $\begin{array}{c}\mathrm{CO}_{2} \\
\text { Emissions } \\
\left(\mathrm{tCO}_{2}\right)\end{array}$ \\
\hline 01 & Natural gas & $9448.5 \mathrm{MT}$ & 48 & 2.67 & $25,227.5$ \\
\hline 02 & Solar PV & $3,062,000 \mathrm{kWh}$ & - & $\begin{array}{c}0.041 \mathrm{~kg} \mathrm{CO}{ }_{2} \\
\text { per kWh }\end{array}$ & 125.5 \\
\hline 03 & $\begin{array}{c}\text { Electricity } \\
\text { from MPEB } \\
\text { Grid }\end{array}$ & $38,000 \mathrm{kWh}$ & - & $\begin{array}{c}0.88 \mathrm{~kg} \mathrm{CO} \\
\text { per } \mathrm{kWh}\end{array}$ & 33.44 \\
\hline \multicolumn{6}{|c|}{ Total $\mathrm{CO}_{2}$ Emissions $=25,386.4 \mathrm{tCO}_{2}$} \\
\hline
\end{tabular}


Table 7. Summary of ISI in various modes.

\begin{tabular}{ccc}
\hline Sl. No. & Production mode of HJI & ISI \\
\hline 01 & Independent mode & 6 \\
02 & Existing symbiotic mode & 2 \\
03 & Modified symbiotic mode & 18 \\
\hline
\end{tabular}

The ISI for an improved system of the HJI plant is evaluated as follows: RVA is evaluated as 1533 million Rs, Annual EMP is 300 persons and the total annual $\mathrm{CO}_{2}$ emissions are estimated at $25,386 \mathrm{tCO}_{2}$. Therefore, ISI for the improved system is evaluated as 18 units.

Hence, with the proposed modified system for the HJI industry, the improvement in ISI of the industry is nearly nine times compared to the existing symbiotic system.

\section{Conclusions}

In this study, a quantitative approach for sustainability assessment was used to examine the impact of industrial symbiosis with different technologies. Such an assessment is based on a practical tool of ISI as developed by the authors [17]. The ISI was evaluated for a chemical production plant both in independent and symbiotic modes. The results obtained are summarized in Table 7.

The following conclusions are drawn from the results obtained:

1) The industrial symbiosis can help in sustainability improvement when the technologies used by the industries are efficient and sustainable.

2) With inefficient technologies such as coal-fired CHP plant, it was observed that sustainability could not be improved even in the symbiotic mode. Rather, the ISI value in the independent mode was more because of the more efficient technology used in the grid electric supply.

3) Thus the role of technology in improving industrial sustainability is very significant.

4) By examining the role of energy-efficient and sustainable technologies, one can assess the feasibility of sustainability improvement in the industrial sector.

Similar studies should be carried out for other industries working in a symbiotic mode, not only in India but also at other locations in the world. This would help in a better understanding of the dynamics of industrial cooperation, and facilitate the adoption of appropriate technologies for improving industrial sustainability.

\section{Acknowledgements}

The authors gratefully acknowledge the help and support received from the management of Hukum Chand Jute Industry at Amlai, Shahdol, Madhya Pradesh, India in obtaining the energy use and production data from the plant. The authors also gratefully acknowledge the constructive and useful suggestions by the anonymous reviewers for improving this manuscript. 


\section{Conflicts of Interest}

The authors declare no conflicts of interest regarding the publication of this paper.

\section{References}

[1] International Energy Agency (2012) $\mathrm{CO}_{2}$ Emissions from Fuel Combustion. Beyond 2020 Online Database. 2012 Edition. http://data.iea.org

[2] Energy Statistic, Central Statistics Office Ministry of Statistics and Programme Implementation Government of India New Delhi. http://mospi.nic.in/sites/default/files/publication_reports/Energy_Statistics_2018.pdf

[3] Lowe, E.A. and Evans, L.K. (1995) Industrial Ecology and Industrial Ecosystems. Journal of Cleaner Production, 3, 7-53. https://doi.org/10.1016/0959-6526(95)00045-G

[4] Susur, E., Hidalgo, A. and Chiaroni, D. (2019) The Emergence of Regional Industrial Ecosystem Niches: A Conceptual Framework and a Case Study. Journal of Cleaner Production, 208, 1642-1657. https://doi.org/10.1016/j.jclepro.2018.10.163

[5] Fiksel, J., McDaniel, J. and Spitzley, D. (1998) Measuring Product Sustainability. The Journal of Sustainable Product Design, 6, 7-19.

[6] Dickinson, D.A. and Caudill, R.J. (2003) Sustainable Product and Material End-ofLife Management: An Approach for Evaluating Alternatives. Proceedings of the IEEE International Symposium on Electronics and the Environment, Boston, 19-22 May 2003, 153-158. https://doi.org/10.1109/ISEE.2003.1208065

[7] Gao, M., Zhou, M. and Wang, F. (2003) Improvement of Product Sustainability. Proceedings of the 2003 IEEE International Conference on Robotics \& Automation, Taipei, 14-19 September 2003, 3548-3553.

[8] Schmidt, W.P. and Butt, F. (2006) Life-Cycle Tools within Ford of Europe's Product Sustainability Index. International Journal Life-Cycle Assessment, 11, 315-322. https://doi.org/10.1065/lca2006.08.267

[9] Industry, Innovation, and Infrastructure. https://unstats.un.org/sdgs/report/2016/goal-09

[10] Mickwitz, P., Melanen, M., Rosenstro, U. and Seppaa, J. (2006) Regional Eco-Efficiency Indicators: A Participatory Approach. Journal of Cleaner Production, 14, 1603-1611. https://doi.org/10.1016/j.jclepro.2005.05.025

[11] Hahn, T., Figge, F., Liesen, A. and Barkemeyer, R. (2010) Opportunity Cost-Based Analysis of Corporate Eco-Efficiency: A Methodology and Its Application to the $\mathrm{CO}_{2}$-Efficiency of German Companies. Journal of Environmental Management, 91, 1997-2007. https://doi.org/10.1016/j.jenvman.2010.05.004

[12] Kerr, W. and Ryan, C. (2001) Eco-Efficiency Gains from Remanufacturing: A Case Study of Photocopier Remanufacturing at Fuji Xerox Australia. Journal of Cleaner Production, 9, 75-81. https://doi.org/10.1016/S0959-6526(00)00032-9

[13] Omrcen, E. (1995) The Product Ecology Project: Creating Prerequisites for Environmentally Adjusted Product Development. Journal of Cleaner Production, 3, 89-93. https://doi.org/10.1016/0959-6526(95)00061-I

[14] Lawrence, A., Thollander, P., Andrei, M. and Karlsson, M. (2019) Specific Energy Consumption/Use (SEC) in Energy Management for Improving Energy Efficiency in Industry: Meaning, Usage, and Differences. Energies, 12, 247.

https://doi.org/10.3390/en12020247 
[15] WBCSD (World Business Council for Sustainable Development) (2000) Eco-Efficiency: Creating More Value with Less Impact. Geneva.

[16] Koulton, P. (2010) Materials and Sustainable Development. Progress in Natural Science: Materials International, 20, 16-29. https://doi.org/10.1016/S1002-0071(12)60002-1

[17] Pandey, A.K. and Prakash, R. (2018) Industrial Sustainability Index and Its Possible Improvement for Paper Industry. Open Journal of Energy Efficiency, 7, 118-128. https://doi.org/10.4236/ojee.2018.74008

[18] Taddeo, R. and Simboli, A.M. (2012) Implementing Eco-Industrial Parks in Existing Clusters. Findings from a Historical Italian Chemical Site. Journal of Cleaner Production, 33, 22-29. https://doi.org/10.1016/j.jclepro.2012.05.011

[19] Zhang, H., Dong, L., Li, H., Fujita, T., Ohnishi, S. and Tang, Q. (2013) Analysis of Low-Carbon Industrial Symbiosis Technology for Carbon Mitigation in a Chinese Iron/Steel Industrial Park: A Case Study with Carbon Flow Analysis. Energy Policy, 61, 1400-1411. https://doi.org/10.1016/j.enpol.2013.05.066

[20] Notarnicola, B., Tassielli, G. and Renzulli, P.A. (2016) Industrial Symbiosis in the Taranto Industrial District: Current Level, Constraints, and Potential New Synergies. Journal of Cleaner Production, 122, 133-143. https://doi.org/10.1016/j.jclepro.2016.02.056

[21] Berkel, R.V., Fuita, T., Hashimoto, S. and Fujii, M. (2009) Quantitative Assessment of Urban and Industrial Symbiosis in Kawasaki, Japan. Environmental Science \& Technology, 43, 1271-1281. https://doi.org/10.1021/es803319r

[22] Ohnishi, S., Dong, H., Geng, Y., Fujii, M. and Fujita, T. (2017) A Comprehensive Evaluation of Industrial \& Urban Symbiosis by Combining MFA, Carbon Footprint and Emergy Methods-Case of Kawasaki, Japan. Ecological Indicators, 73, 513-524. https://doi.org/10.1016/j.ecolind.2016.10.016

[23] Zhang, Y., Duan, S., Li, J., Shao, S., Wang, W. and Zhang, S. (2017) Life Cycle Assessment of Industrial Symbiosis in Songmudao Chemical Industrial Park, Dalian, China. Journal of Cleaner Production, 158, 192-199. https://doi.org/10.1016/j.jclepro.2017.04.119

[24] Sharma, S.K. (2012) Global Warming and Carbon Footprint: A New Challenge for Indian Chemical Industry. Indian Chemical Engineer, 54, 36-51. https://doi.org/10.1080/00194506.2012.730685

[25] Prakash, R. and Henham, A. (2014) Decentralized Energy Systems for Dairy Industry. International Journal of Environmental Sustainability, 9, 1-9. https://doi.org/10.18848/2325-1077/CGP/v09i03/55096

[26] Pandey, A.K. and Prakash, R. (2018) Energy Conservation Opportunities in Pulp \& Paper Industry. Open Journal of Energy Efficiency, 7, 89-99. https://doi.org/10.4236/ojee.2018.74006

[27] Intergovernmental Panel on Climate Change (2006) IPCC Guidelines for National Green House Gas Inventories. Vol. 2, Energy.

[28] ETMARKETS the Economic Times. https://economictimes.indiatimes.com/commoditysummary/symbol-NATURALG AS.cms 